\title{
Analysis of Organoiodide Adsorption Mechanisms
}

Nuclear Technology

Research and Development







\section{DISCLAIMER}

This information was prepared as an account of work sponsored by an agency of the U.S. Government. Neither the U.S. Government nor any agency thereof, nor any of their employees, makes any warranty, expressed or implied, or assumes any legal liability or responsibility for the accuracy, completeness, or usefulness, of any information, apparatus, product, or process disclosed, or represents that its use would not infringe privately owned rights. References herein to any specific commercial product, process, or service by trade name, trade mark, manufacturer, or otherwise, does not necessarily constitute or imply its endorsement, recommendation, or favoring by the U.S. Government or any agency thereof. The views and opinions of authors expressed herein do not necessarily state or reflect those of the U.S. Government or any agency thereof. 


\section{SUMMARY}

If the United States were to engage in the reprocessing of used nuclear fuel, radioactive iodine must be removed from multiple plant off-gas streams to comply with governing regulations. One of these streams is the vessel off-gas (VOG), which arises from the separations process and is expected to contain iodine in primarily organic iodine forms and at parts-per-billion concentrations. The relative lack of knowledge surrounding organic iodine removal from the VOG prompted the US Department of Energy's Office of Nuclear Energy to initiate experimental efforts targeted at understanding organic iodide removal from prototypic VOG streams. At Oak Ridge National Laboratory (ORNL), this effort has focused on developing a comprehensive understanding of iodine removal from VOG streams by using silver-based sorbents. An important aspect of this testing is developing an understanding of how the sorption of methyl iodide $\left(\mathrm{CH}_{3} \mathrm{I}\right)$, the most studied organic iodide species to date, compares with the sorption of other volatile organic iodide species potentially present in the VOG.

The work presented here reflects initial testing that will continue to be developed, and final results will be incorporated into an end-of-year report that details a multiyear testing campaign designed to understand iodine mitigation from VOG streams. The goal of these experiments was to determine whether similar reaction pathways govern both $\mathrm{CH}_{3} \mathrm{I}$ and iodobutane $\left(\mathrm{C}_{4} \mathrm{H}_{9} \mathrm{I}\right)$ sorption onto silver mordenite $(\mathrm{AgZ})$, a common silver-based iodine sorbent. More specifically, the authors hypothesized that the sorption of $\mathrm{C}_{4} \mathrm{H}_{9} \mathrm{I}$ by $\mathrm{AgZ}$ will result in the formation of butanol $\left(\mathrm{C}_{4} \mathrm{H}_{9} \mathrm{OH}\right)$. Effluent monitoring of $\mathrm{CH}_{3} \mathrm{I}$ sorption testing has confirmed methanol production, but analogous monitoring of effluents from $\mathrm{C}_{4} \mathrm{H}_{9} \mathrm{I}$ sorption studies has not been performed.

A series of tests was completed to test this hypothesis with the aim of detecting $\mathrm{C}_{4} \mathrm{H}_{9} \mathrm{OH}$ downstream of the AgZ bed. Test conditions varied the bed depth, gas stream humidity, and bed temperature post sorption. The effluent gas stream downstream of the $\mathrm{AgZ}$ bed was sampled by using gas-tight syringes, and these samples were analyzed by a gas chromatograph coupled to a mass spectrometer.

Thin bed $\mathrm{C}_{4} \mathrm{H}_{9} \mathrm{I}$ tests conducted at -65 and $0^{\circ} \mathrm{C}$ dew points did not result in $\mathrm{C}_{4} \mathrm{H}_{9} \mathrm{OH}$ detection in the effluent. This suggests that the sorption mechanism and subsequent reactions could be different from those observed for $\mathrm{CH}_{3} \mathrm{I}$. The sorption testing continues; additional results will be included in final end-of-year report and will increase the fundamental understanding of organic iodide sorption by AgZ from VOG streams. 


\section{CONTENTS}

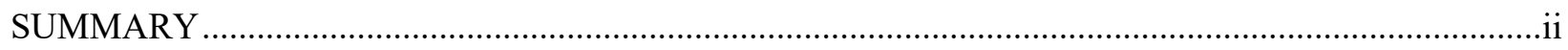

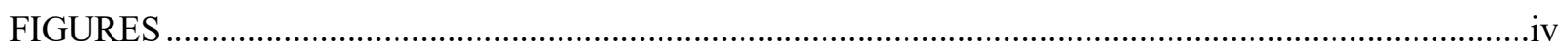

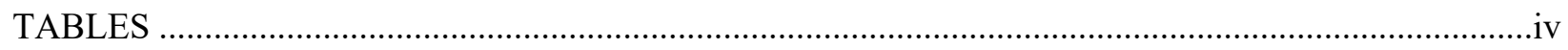

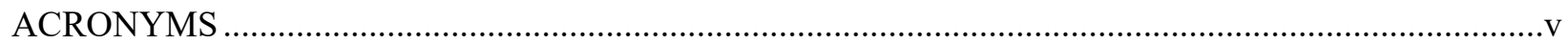

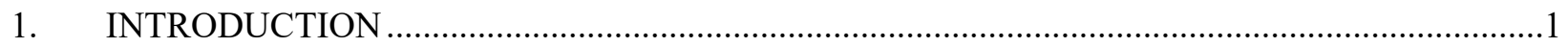

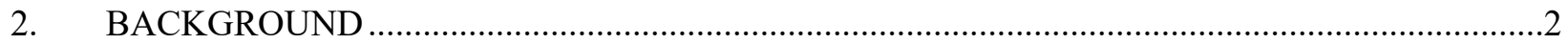

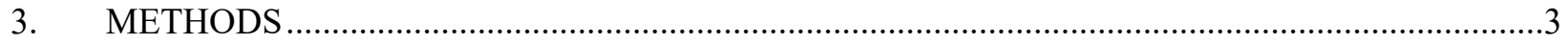



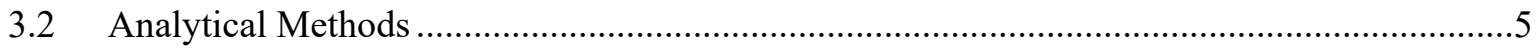

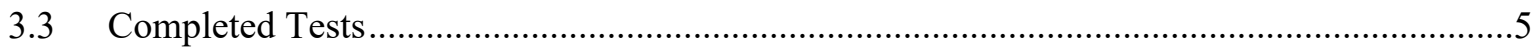

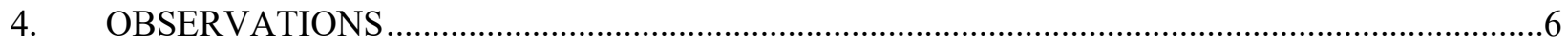

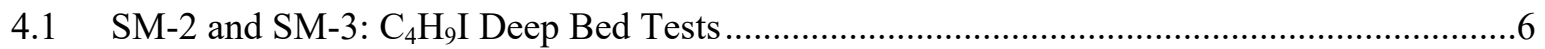

4.2 SM-4 and SM-5: $\mathrm{C}_{4} \mathrm{H}_{9}$ I Thin Bed Tests.........................................................................

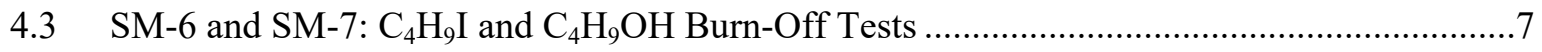

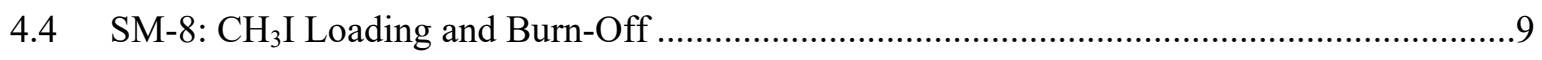

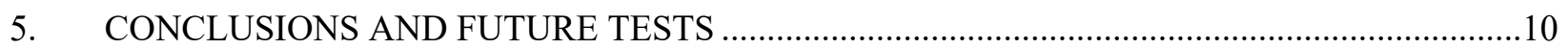

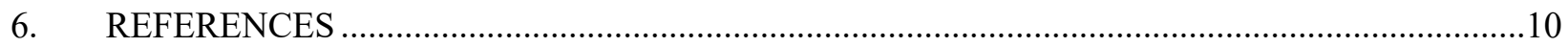




\section{FIGURES}

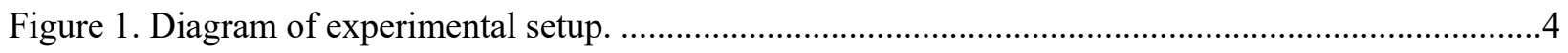

Figure 2. Chromatographs showing examples of calibration standards analyzed. The $y$-axis is the counts (not to scale between figures), and the $x$-axis is time. Purple is $100 \mathrm{ppm}$, black is $50 \mathrm{ppm}$, green is $10 \mathrm{ppm}$, and orange is $1 \mathrm{ppm}$.

Figure 3. Chromatograph showing a syringe background sample (black, $\sim 6 \mathrm{ppm}$ ) and an effluent sample from the humid SM-3 test (blue, $\sim 12 \mathrm{ppm}$ ). $\mathrm{C}_{4} \mathrm{H}_{9} \mathrm{OH}$ (peak at $10 \mathrm{~min}$ ) is present in both samples, suggesting that contamination from the syringe could account for $\mathrm{C}_{4} \mathrm{H}_{9} \mathrm{OH}$ signals observed in the effluents of SM-2 and SM-3.

Figure 4. Loading rates of $\mathrm{CH}_{3} \mathrm{I}$ and $\mathrm{C}_{4} \mathrm{H}_{9} \mathrm{I}$ on thin bed tests recorded by TGA. 9

\section{TABLES}

Table 1: Proposed $\mathrm{CH}_{3} \mathrm{I}$ sorption pathways. Synthesized from Scheele et al. (1983) and Huve et al.(2018).

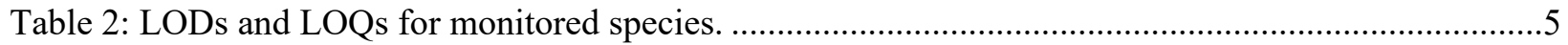

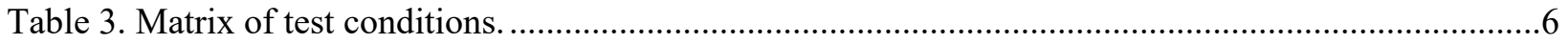

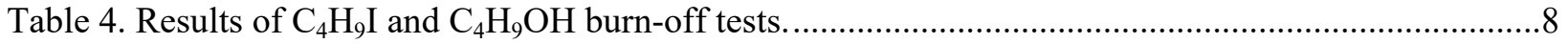




\section{ACRONYMS}

$\begin{array}{ll}\mathrm{AgI} & \text { silver iodide } \\ \mathrm{AgZ} & \text { silver mordenite } \\ \mathrm{BDL} & \text { below limit of detection } \\ \mathrm{BQL} & \text { below limit of quantification } \\ \mathrm{C}_{2} \mathrm{H}_{6} & \text { ethane } \\ \mathrm{CH}_{3} \mathrm{I} & \text { methyl iodide } \\ \mathrm{CH}_{3} \mathrm{OH} & \text { methanol } \\ \mathrm{C}_{4} \mathrm{H}_{9} \mathrm{I} & \text { iodobutane } \\ \mathrm{C}_{4} \mathrm{H}_{9} \mathrm{OH} & \text { butanol } \\ \mathrm{C}_{12} \mathrm{H}_{25} \mathrm{I} & \text { iodododecane } \\ \mathrm{DF} & \text { decontamination factor } \\ \mathrm{DME} & \text { DME } \\ \mathrm{DOG} & \text { dissolver off-gas } \\ \mathrm{GC} & \text { gas chromatography } \\ \mathrm{GC}-\mathrm{MS} & \text { gas chromatography-mass spectrometry } \\ \mathrm{I}_{2} & \text { elemental iodine } \\ \mathrm{INL} & \text { Idaho National Laboratory } \\ \text { LOD } & \text { limit of detection } \\ \text { LOQ } & \text { limit of quantification } \\ \mathrm{MS} & \text { mass spectrometer } \\ \mathrm{ORNL} & \text { Oak Ridge National Laboratory } \\ \mathrm{SPME} & \text { solid phase microextraction } \\ \mathrm{TGA} & \text { thermogravimetric analyzer } \\ \text { VOG } & \text { vessel off-gas } \\ & \end{array}$





\section{ANALYSIS OF ORGANOIODIDE ADSORPTION MECHANISMS}

\section{INTRODUCTION}

The aqueous reprocessing of used nuclear fuel releases four key volatile radionuclides $-{ }^{3} \mathrm{H},{ }^{14} \mathrm{C},{ }^{85} \mathrm{Kr}$, and ${ }^{129} \mathrm{I}$ - from the used fuel into the off-gas streams of a reprocessing facility. Off-gas streams, which typically converge to one environmental discharge point, are treated within the facility to remove volatile radionuclides. Analysis shows that of these four volatile elements, iodine will require the highest level of removal to comply with US Environmental Protection Agency regulations (Jubin et al. 2012). An evaluation was conducted that assessed the practical impact of these regulations, and it found that an overall plant decontamination factor (DF) ${ }^{\mathrm{a}}$ of 1,000 is likely the minimum required iodine abatement efficiency (Jubin et al. 2017). Depending on the specifics of the reprocessing facility and reprocessed fuel, the required DF could be as high as 8,000 .

Iodine is released during multiple unit operations within the plant and can be found in gas streams such as the shear off-gas, dissolver off-gas (DOG), solvent extraction vessel off-gas (VOG), and waste solidification off-gas. An analysis of the distribution of iodine between aqueous separations unit operations found that 95 $99 \%$ of total iodine release to the off-gas occurs during dissolution, releasing iodine into the DOG, and also found that much of the balance of the iodine is released during solvent extraction, releasing the iodine into the VOG (Jubin et al. 2013). To achieve DFs greater than 1,000, the treatment of the plant off-gas streams must include, at minimum, the treatment of both DOG and VOG.

Removing iodine from the DOG has been the subject of substantial research and development in recent years. Iodine is primarily present in the DOG as elemental iodine $\left(\mathrm{I}_{2}\right)$ and is typically removed by using silver-based sorbent materials or aqueous caustic scrubbing. Interest in removing iodine from the VOG has also recently increased, and a 2015 analysis showed that the iodine speciation in the VOG primarily comprises organic alkyl iodides and that abatement technology for organic iodides is not well developed (Bruffey et al. 2015). Furthermore, the concentration of iodine in the VOG (parts per billion by volume levels) is substantially lower than that of the DOG (parts per million by volume levels), and the characteristics of the two gas streams differ in total flow rate, volume, and composition.

Because iodine abatement within the VOG might be a critical requirement for an eventual reprocessing facility, the relative lack of knowledge that surrounds iodine removal from the VOG prompted the US Department of Energy's Office of Nuclear Energy to initiate experimental efforts targeted at understanding organic iodide removal from prototypic VOG streams. At Oak Ridge National Laboratory (ORNL), this effort has focused on developing a comprehensive understanding of iodine removal from VOG streams by using silver-based sorbents (Jubin et al. 2017, Jubin et al. 2018, Bruffey et al. 2018). Variables such as the mass transfer zone of the sorbent bed, gas velocity, sorbate concentration, and sorbate speciation are being explored to determine their effects on iodine removal from VOG streams. One important aspect of this testing is developing an understanding of how the sorption of methyl iodide $\left(\mathrm{CH}_{3} \mathrm{I}\right)$, the most studied organic iodide species to date, compares with the sorption of other volatile organic iodide species potentially present in the VOG. Tests at ORNL and Idaho National Laboratory (INL) have investigated the sorption of the longer chain alkyl iodides iodobutane $\left(\mathrm{C}_{4} \mathrm{H}_{9} \mathrm{I}\right)$ and iodododecane $\left(\mathrm{C}_{12} \mathrm{H}_{25} \mathrm{I}\right)$ to understand how iodine speciation might affect iodine sorption by silver-based sorbents (Bruffey et al. 2019).

The experiments described in this report were conducted as part of the larger effort to understand organic iodine removal from the VOG. This work aimed to incorporate effluent monitoring into ORNL testing to

\footnotetext{
${ }^{\mathrm{a}} \mathrm{DF}=\frac{\text { concentration of radionuclide in a control device inlet gas }}{\text { concentration of radionuclide in a control device outlet gas }}$ 
provide more insight into the reaction pathways of $\mathrm{C}_{4} \mathrm{H}_{9} \mathrm{I}$ sorption by silver mordenite (AgZ), a common silver-based zeolite mineral sorbent. Much of the testing at ORNL to date has been limited to continuous weight measurements via a custom thermogravimetric analyzer (TGA) and posttest sorbent analysis for total iodine content. These measurements provide insight into loading rates and sorbent iodine capacity values across a range of operating conditions, but they cannot provide insight into the specific sorption mechanisms that drive sorption rates or capacities.

The experiments described in this report extend the current understanding of organic iodide sorption by zeolites. The literature reflects knowledge of the reaction pathways that govern $\mathrm{CH}_{3} \mathrm{I}$ sorption, but it does not address whether similar pathways can be validated for other iodine-bearing species. This work reflects initial testing that will continue to be developed, and an end-of-year report will detail the final results of the multiyear testing campaign designed to understand iodine mitigation from VOG streams.

\section{BACKGROUND}

There is a dense body of literature surrounding the sorption of organic iodides, primarily $\mathrm{CH}_{3} \mathrm{I}$, by silverbased sorbents, as documented in a review article by Huve et al. (2018). A formal review of this information is outside the scope of this report, but relevant portions are discussed in this section to provide an understanding of the test aims and experimental approach.

Some of the earliest documentation of potential sorption pathways for $\mathrm{CH}_{3} \mathrm{I}$ by $\mathrm{AgZ}$ is found in Scheele et al. (1983). Scheele et al. tabulated the free energies of many relevant reactions, including those of $\mathrm{I}_{2}$ sorption by $\mathrm{AgZ}$ with and without the presence of $\mathrm{NO}_{\mathrm{x}}$ gas in the initial feed stream. Huve et al. (2018) provides a more condensed list of potentially applicable reactions. Reactions from these papers are provided in Table 1, and the free energies are updated in this document by using the thermodynamic calculation software HSC Chemistry Version 9 (Outotec 2018) for three temperatures. Studies also show that the sorption of $\mathrm{CH}_{3} \mathrm{I}$ by $\mathrm{AgZ}$ is catalyzed by the zeolite surface itself (Nenoff et al. 2014). This is reflected in Table 1 by the inclusion of Reaction 0, a decomposition of $\mathrm{CH}_{3} \mathrm{I}$ to a $\mathrm{CH}_{3}$-zeolite complex. The $\mathrm{CH}_{3}$-zeolite complex can then continue to react to form methanol $\left(\mathrm{CH}_{3} \mathrm{OH}\right)$ or other organic compounds. Catalysis of $\mathrm{CH}_{3} \mathrm{I}$ by the zeolite surface might facilitate some or all of equations $1-6$ in Table 1.

Table 1: Proposed $\mathrm{CH}_{3} \mathrm{I}$ sorption pathways. Synthesized from Scheele et al. (1983) and Huve et al.(2018).

\begin{tabular}{|c|l|c|c|c|}
\hline \multirow{2}{*}{ Equation } & \multicolumn{1}{|c|}{ Proposed sorption reactions } & \multicolumn{3}{|c|}{$\Delta \mathbf{G}_{\text {reaction }}$ (kcal) } \\
\cline { 3 - 5 } & & $300 \mathrm{~K}$ & $400 \mathrm{~K}$ & $500 \mathrm{~K}$ \\
\hline 0 & $\mathrm{CH}_{3} \mathrm{I}+\mathrm{Ag}$-zeolite $\leftrightarrow \mathrm{CH}_{3}$-zeolite $+\mathrm{AgI}$ & \multicolumn{3}{|c|}{ Not tabulated } \\
\hline 1 & $2 \mathrm{Ag}+2 \mathrm{CH}_{3} \mathrm{I}(g) \rightarrow 2 \mathrm{AgI}+\mathrm{C}_{2} \mathrm{H}_{6}(g)$ & -46.9 & -43.9 & -41.5 \\
\hline 2 & $\mathrm{Ag}+\mathrm{CH}_{3} \mathrm{I}(g)+\mathrm{H}_{2} \mathrm{O}(g) \rightarrow \mathrm{AgI}+\mathrm{CH}_{3} \mathrm{OH}(g)+1 / 2 \mathrm{H}_{2}$ & -7.6 & -4.6 & -2.4 \\
\hline 3 & $\mathrm{Ag}+\mathrm{CH}_{3} \mathrm{I}(g)+\mathrm{CH}_{3} \mathrm{OH} \rightarrow \mathrm{AgI}+\mathrm{CH}_{3} \mathrm{OCH}(g)+1 / 2 \mathrm{H}_{2}$ & -15.7 & -11.7 & -8.5 \\
\hline 4 & $\mathrm{Ag}(a q)+\mathrm{CH}_{3} \mathrm{I}(g)+\mathrm{H}_{2} \mathrm{O}(g) \rightarrow \mathrm{AgI}+\mathrm{CH}_{3} \mathrm{OH}(g)+\mathrm{H}^{+}(a q)$ & -22.2 & -18.3 & -14.7 \\
\hline 5 & $7 \mathrm{NO}^{2}+2 \mathrm{CH}_{3} \mathrm{I}(g) \rightarrow \mathrm{I}_{2}(g)+2 \mathrm{CO}_{2}+3 \mathrm{H}_{2} \mathrm{O}(g)+7 / 2 \mathrm{~N}_{2}$ & -500.4 & -499.1 & -497.8 \\
\hline 6 & $7 \mathrm{NO}_{2}(\mathrm{~g})+4 \mathrm{CH}_{3} \mathrm{I}(g) \rightarrow \mathrm{I}_{2}(g)+4 \mathrm{CO}_{2}+6 \mathrm{H}_{2} \mathrm{O}(g)+7 / 2 \mathrm{~N}_{2}$ & -398.4 & -404.4 & -410.5 \\
\hline
\end{tabular}


In Reactions 1-4, the iodine-bearing absorbed species is solid silver iodide (AgI), which can be present in multiple crystalline forms, depending on specific sorption conditions (Chapman et al. 2010). Beyond AgI production, several key organic byproducts could also be present, depending on the reaction pathway. Reaction 1 produces ethane $\left(\mathrm{C}_{2} \mathrm{H}_{6}\right)$, Reaction 2 produces $\mathrm{CH}_{3} \mathrm{OH}$, and Reaction 3 provides a pathway for the $\mathrm{CH}_{3} \mathrm{OH}$ to further react and form dimethyl ether (DME).

In Reactions 5 and 6, AgI is not identified as the product, and the $\mathrm{NO}$ (Reaction 5) or $\mathrm{NO}_{2}$ (Reaction 6) reactant serves to facilitate the production of free $\mathrm{I}_{2}$. This $\mathrm{I}_{2}$ could be assumed to continue to react and adsorb onto the $\mathrm{AgZ}$, indicating that more complex reaction pathways will be present in $\mathrm{NO}_{\mathrm{x}}$-bearing gas streams.

These proposed reactions have been supported through the observation of the suggested byproducts in the gaseous effluent streams of $\mathrm{CH}_{3} \mathrm{I}$ sorption experiments. INL has verified the presence of $\mathrm{CH}_{3} \mathrm{OH}$ and DME in the effluent streams of $\mathrm{CH}_{3} \mathrm{I} / \mathrm{AgZ}$ sorption experiments (Soelberg and Watson 2016), validating Reactions 2 and 3. Chebbi et al. (2016) also reported $\mathrm{CH}_{3} \mathrm{OH}$ and DME in the effluents of similar sorption testing.

Additional studies have been added to the literature surrounding the fundamental mechanisms and characteristics of $\mathrm{CH}_{3} \mathrm{I}$ sorption by $\mathrm{AgZ}$ or other zeolites (Azambre et al. 2017, Chebbi et al. 2017, Huve et al. 2018, Tang et al. 2020, Chebbi et al. 2021). One remaining question relates to the role of water in the $\mathrm{CH}_{3} \mathrm{I} / \mathrm{AgZ}$ sorption reaction. Chebbi et al. (2021) describes some of the published conflicting studies on the role of water in the sorption of $\mathrm{CH}_{3} \mathrm{I}$ by AgZ. Recent studies by ORNL confirm that water plays less of a role in $\mathrm{CH}_{3} \mathrm{I}$ sorption than initially thought, despite a significant difference in observed loading rates, depending on whether water is present in the gas feed stream. Greaney et al. (2020) found no statistical difference observed in the loading capacity of $\mathrm{AgZ}$ for $\mathrm{CH}_{3} \mathrm{I}$ from dry and humid gas streams. The findings of Greaney et al. (2020) broadly align with the findings of Chebbi et al. (2021).

The work described here focuses on the sorption of $\mathrm{C}_{4} \mathrm{H}_{9} \mathrm{I}$ by $\mathrm{AgZ}$ and attempts to determine whether the sorption reactions that govern $\mathrm{CH}_{3} \mathrm{I}$ can be translated to the sorption of $\mathrm{C}_{4} \mathrm{H}_{9} \mathrm{I}$. Specifically, the authors hypothesized that the sorption of $\mathrm{C}_{4} \mathrm{H}_{9} \mathrm{I}$ by $\mathrm{AgZ}$ will result in the formation of butanol $\left(\mathrm{C}_{4} \mathrm{H}_{9} \mathrm{OH}\right)$. A series of thin and deep bed sorption tests were performed, and the gaseous effluents were analyzed by gas chromatography (GC) coupled to a mass spectrometer (MS). Given the uncertainties surrounding the impact of water on organic iodine sorption, experiments were performed by using dry and humidified feed gas streams. Future reports will use these data to provide insights into organic iodide removal from VOG streams across a spectrum of fundamental and applied scales.

\section{METHODS}

Experimental methods included exposing thin and deep beds of reduced $\mathrm{AgZ}$ to dry and humid iodinebearing feed streams. Effluent monitoring of the sorbate $\left(\mathrm{C}_{4} \mathrm{H}_{9} \mathrm{I}\right)$ and potential organic product $\left(\mathrm{C}_{4} \mathrm{H}_{9} \mathrm{OH}\right)$ was performed by gas chromatography-mass spectrometry (GC-MS). Validating experimental methodology included some testing with $\mathrm{CH}_{3} \mathrm{I}$ as the sorbate, and in these tests, $\mathrm{CH}_{3} \mathrm{I}$ and $\mathrm{CH}_{3} \mathrm{OH}$ were monitored. Although DME is also known to be produced in the sorption of $\mathrm{CH}_{3} \mathrm{I}$ by $\mathrm{AgZ}$, its release is near simultaneous with $\mathrm{CH}_{3} \mathrm{OH}$, and it is of lower abundance (Chebbi et al. 2021). Thus, monitoring for $\mathrm{CH}_{3} \mathrm{OH}$ or $\mathrm{C}_{4} \mathrm{H}_{9} \mathrm{OH}$ was judged sufficient to confirm reaction pathways.

\subsection{Experimental Methods}

$\mathrm{AgZ}$ was obtained from molecular products in an engineered pelletized form (Ionex-Type Ag $900 \mathrm{E} 16$ ). It contains $11.9 \%$ silver by weight and has a $0.16 \mathrm{~cm}$ pellet diameter. Before use in testing, the sorbent material was dried at $270^{\circ} \mathrm{C}$ under flowing argon gas for 3 days. It was then reduced by 10 day exposure to a flowing $\mathrm{H}_{2}-\mathrm{N}_{2}(4-96 \%)$ blend gas at $270^{\circ} \mathrm{C}$. 
A test system was designed so that two beds could be loaded simultaneously and their effluents could be sampled for GC-MS analysis (Figure 1). Columns with $2.73 \mathrm{in}$. internal diameter were used, and the flow rate was kept constant at 3.94 LPM. One column received humid air or dry air, and the second column received dry air. All sorbent loading was conducted at $150^{\circ} \mathrm{C}$, and the burn-off temperatures of two tests reached $225^{\circ} \mathrm{C}$. Nitrogen-sparged bubblers were used to generate the organic species of interest (i.e., $\mathrm{CH}_{3} \mathrm{I}$, $\mathrm{C}_{4} \mathrm{H}_{9} \mathrm{I}$, or $\mathrm{C}_{4} \mathrm{H}_{9} \mathrm{OH}$ ). The inlet concentrations of the monitored products were verified through GC-MS analysis.

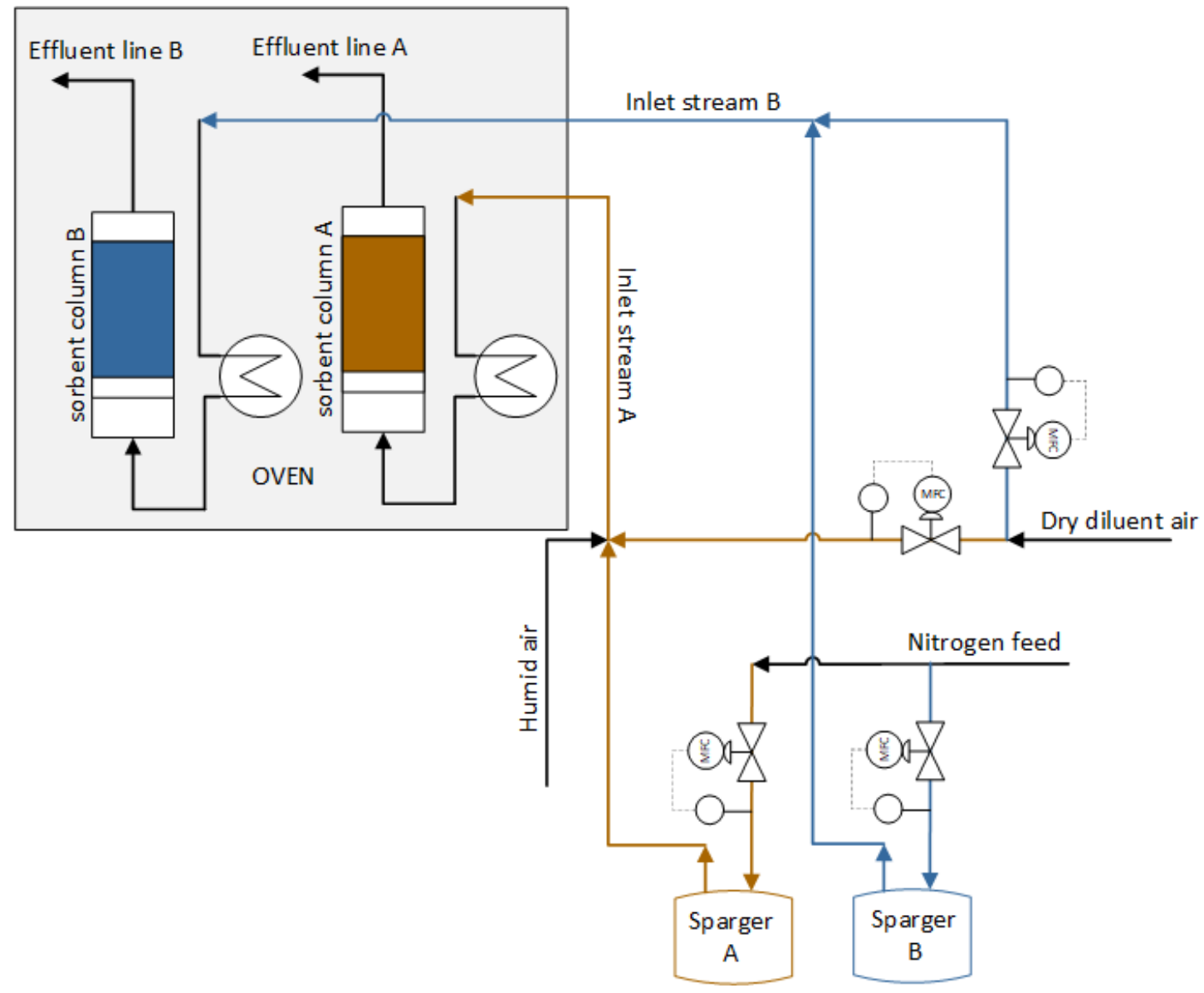

Figure 1. Diagram of experimental setup.

Multiple downstream sampling systems were tested for GC-MS analysis, including solid phase microextraction (SPME) fibers, capturing the effluent in flow-through gas-tight sampling vials and directly sampling the effluent with a gas-tight syringe. The SPME fibers were difficult to clean, which resulted in carryover between samples. The flow-through sampling vial resulted in imprecise data when it was used with one concentration gas stream. The most accurate and precise sampling method was determined to be the direct sampling of the effluent by using headspace syringes. 


\subsection{Analytical Methods}

Effluent samples were analyzed on an Agilent 8890-5977B GC-MS with a 30 m DB-624-UI ultra-inert capillary column. The GC method was designed to capture iodoalkanes ranging from methyl to dodecyl iodide. The inlet temperature remains at $250^{\circ} \mathrm{C}$ while the column temperature starts at $30^{\circ} \mathrm{C}$ for 5 minutes before ramping to $220^{\circ} \mathrm{C}$ at a rate of $10^{\circ} \mathrm{C} /$ minute before holding at $220^{\circ} \mathrm{C}$ for 6 minutes. Helium is used as the carrier gas with a constant flow rate of $1.2 \mathrm{ml} / \mathrm{min}$. The column effluent is analyzed on a single-quad mass spectrometer and the data are analyzed using the Agilent MassHunter software. Manual injections were of $200 \mu \mathrm{l}$ sample volumes were done with gas-tight syringes. Methanol is detected on the chromatograph at $3 \mathrm{~min}, \mathrm{CH}_{3} \mathrm{I}$ is detected at $4.5 \mathrm{~min}, \mathrm{C}_{4} \mathrm{H}_{9} \mathrm{OH}$ is detected at $10.1 \mathrm{~min}$, and $\mathrm{C}_{4} \mathrm{H}_{9} \mathrm{I}$ is detected at 13.2 min (Figure 2). An additional ramp temperature of $30 \mathrm{~min}$ to $220^{\circ} \mathrm{C}$ is included to ensure that $\mathrm{C}_{4} \mathrm{H}_{9} \mathrm{OH}$ fully burns off the column and is not carried over from sample to sample. Column and syringe backgrounds were analyzed at least once daily (often multiple times a day) by injecting $200 \mu 1$ of room air into the GC-MS and running the aforementioned method.
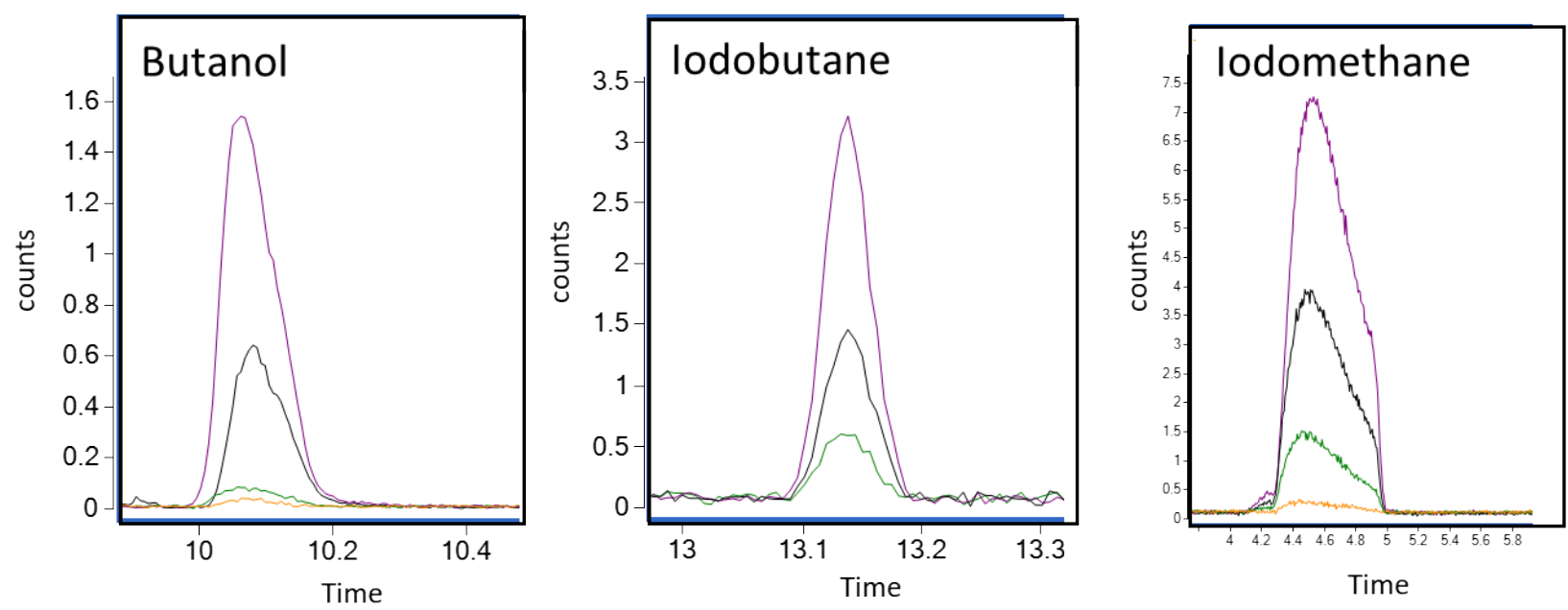

Figure 2. Chromatographs showing examples of calibration standards analyzed. The $y$-axis is the counts (not to scale between figures), and the $x$-axis is time. Purple is $100 \mathrm{ppm}$, black is $50 \mathrm{ppm}$, green is $10 \mathrm{ppm}$, and orange is $1 \mathrm{ppm}$.

Gas-phase calibration standards were created by using the same sampling methods as the experiments. Standards were created at 1,10,50, and $100 \mathrm{ppm}$. Peak areas integrated by the Agilent MassHunter software are used for quantification. Limits of detection (LODs) and limits of quantification (LOQs) were determined for each species using chromatograph baseline statistics and regression statistics from the calibration curve generated by the standards (Table 2). For reference, the vapor pressures of each compound are also included in Table 2. A 1 ppm standard was not analyzed for iodobutane. Iodomethane does not form a gaussian peak in the chromatograph, possibly due to effects of the compound interacting with the column. This peak broadening is routinely observed for iodomethane across experiments.

Table 2: LODs and LOQs for monitored species.

\begin{tabular}{|c|c|c|c|}
\hline Species & $\begin{array}{c}\text { LOD } \\
(\mathbf{p p m})\end{array}$ & $\begin{array}{c}\text { LOQ } \\
\mathbf{( p p m )}\end{array}$ & $\begin{array}{c}\text { Vapor pressure } \\
(\mathbf{m m H g})\end{array}$ \\
\hline $\mathrm{CH}_{3} \mathrm{I}$ & 0.06 & $0.13 \pm 0.06$ & $400\left(20^{\circ} \mathrm{C}\right)$ \\
\hline $\mathrm{CH}_{3} \mathrm{OH}$ & Not determined & Not determined & $90\left(25^{\circ} \mathrm{C}\right)$ \\
\hline $\mathrm{C}_{4} \mathrm{H}_{9} \mathrm{I}$ & 1 & $12 \pm 1$ & $0.138\left(25^{\circ} \mathrm{C}\right)$ \\
\hline $\mathrm{C}_{4} \mathrm{H}_{9} \mathrm{OH}$ & 3 & $4 \pm 1$ & $4.35\left(20^{\circ} \mathrm{C}\right)$ \\
\hline
\end{tabular}




\subsection{Completed Tests}

Seven tests are reported here, and a summary of test conditions is shown in Table 3; more detailed information is provided in Section 4.

Table 3. Matrix of test conditions.

\begin{tabular}{|l|c|c|c|c|c|c|c|c|}
\hline SM test \# & Species & $\begin{array}{c}\text { Inlet conc. } \\
(\mathbf{p p m})\end{array}$ & Sorbent & $\begin{array}{c}\text { Temp. } \\
\left({ }^{\circ} \mathbf{C}\right)\end{array}$ & $\begin{array}{c}\text { Dew } \\
\text { point } \\
\left({ }^{\circ} \mathbf{C}\right)\end{array}$ & $\begin{array}{c}\text { Carrier } \\
\text { gas }\end{array}$ & $\begin{array}{c}\text { Bed } \\
\text { height } \\
(\mathbf{i n .})\end{array}$ & $\begin{array}{c}\text { Bed } \\
\text { Mass } \\
(\mathbf{g})\end{array}$ \\
\hline FY21-SM-2 & $\mathrm{C}_{4} \mathrm{H}_{9} \mathrm{I}$ & 20 & $\mathrm{Ag}^{0} \mathrm{Z}$ & 150 & -70 & Air & 2 & 45 \\
\hline FY21-SM-3 & $\mathrm{C}_{4} \mathrm{H}_{9} \mathrm{I}$ & 20 & $\mathrm{Ag}^{0} \mathrm{Z}$ & 150 & 10 & Air & 2 & 45 \\
\hline FY21-SM-4 & $\mathrm{C}_{4} \mathrm{H}_{9} \mathrm{I}$ & 50 & $\mathrm{Ag}^{0} \mathrm{Z}$ & 150 & -70 & Air & 1 & 18 \\
\hline FY21-SM-5 & $\mathrm{C}_{4} \mathrm{H}_{9} \mathrm{I}$ & 50 & $\mathrm{Ag}^{0} \mathrm{Z}$ & 150 & 0 & Air & 1 & 18 \\
\hline FY21-SM-6 & $\mathrm{C}_{4} \mathrm{H}_{9} \mathrm{I}$ & 50 & $\mathrm{Ag}^{0} \mathrm{Z}$ & 150 & 0 & Air & 0.25 & 4 \\
\hline FY21-SM-7 & $\mathrm{C}_{4} \mathrm{H}_{9} \mathrm{OH}$ & 50 & $\mathrm{Ag}^{0} \mathrm{Z}$ & 150 & -70 & Air & 0.25 & 4 \\
\hline FY21-SM-8 & $\mathrm{CH}_{3} \mathrm{I}$ & 50 & $\mathrm{Ag}^{0} \mathrm{Z}$ & 150 & 10 & Air & 0.3 & 6 \\
\hline
\end{tabular}

\section{OBSERVATIONS}

\subsection{SM-2 and SM-3: $\mathrm{C}_{4} \mathrm{H}_{9}$ I Deep Bed Tests}

Initial tests to evaluate whether $\mathrm{C}_{4} \mathrm{H}_{9} \mathrm{OH}$ formed during sorption were conducted in deep sorbent beds $(\sim 45 \mathrm{~g}$ of $\mathrm{AgZ}$ in $2 \mathrm{in}$. deep bed). One dry test (SM-2) was conducted at $150^{\circ} \mathrm{C},-70^{\circ} \mathrm{C}$ dew point, and $20 \mathrm{ppm}_{4} \mathrm{H}_{9} \mathrm{I}$ in air, and one humid test (SM-3) was conducted at $150^{\circ} \mathrm{C}, 10^{\circ} \mathrm{C}$ dew point, and $20 \mathrm{ppm} \mathrm{C}_{4} \mathrm{H}_{9} \mathrm{I}$ in air. The dry test ran for 12 days, and the humid test ran for 10 days, allowing portions of the sorbent beds to approach iodine loadings near capacity. The effluent was sampled for GC-MS analysis multiple times on the first day and then daily thereafter. Neither test resulted in detectable $\mathrm{C}_{4} \mathrm{H}_{9} \mathrm{I}$ breakthrough of the $2 \mathrm{in}$. deep bed.

The results of these tests were inconclusive. A transient $\mathrm{C}_{4} \mathrm{H}_{9} \mathrm{OH}$ peak and a cyclobutanol peak were detected in chromatographs from the wet and dry tests. $\mathrm{A} \mathrm{C}_{4} \mathrm{H}_{9} \mathrm{OH}$ peak was present at the $46 \mathrm{~h}$ sample and $96 \mathrm{~h}$ sample but was absent from the $69 \mathrm{~h}$ sample. However, further analysis of the $\mathrm{GC}$ column and syringe background found that the observed $\mathrm{C}_{4} \mathrm{H}_{9} \mathrm{OH}$ might have been a contamination product from unrelated experimental samples that were being analyzed with GC-MS. Column backgrounds were determined by running the GC-MS method with no injection. Syringe backgrounds were determined by sampling $200 \mu \mathrm{L}$ of room air and analyzing that injection with the set GC-MS method (Figure 3). Ultimately, the validity of the $\mathrm{C}_{4} \mathrm{H}_{9} \mathrm{OH}$ results could not be determined for these tests. Additional testing was not performed until other projects that cause potential interferences were completed. 


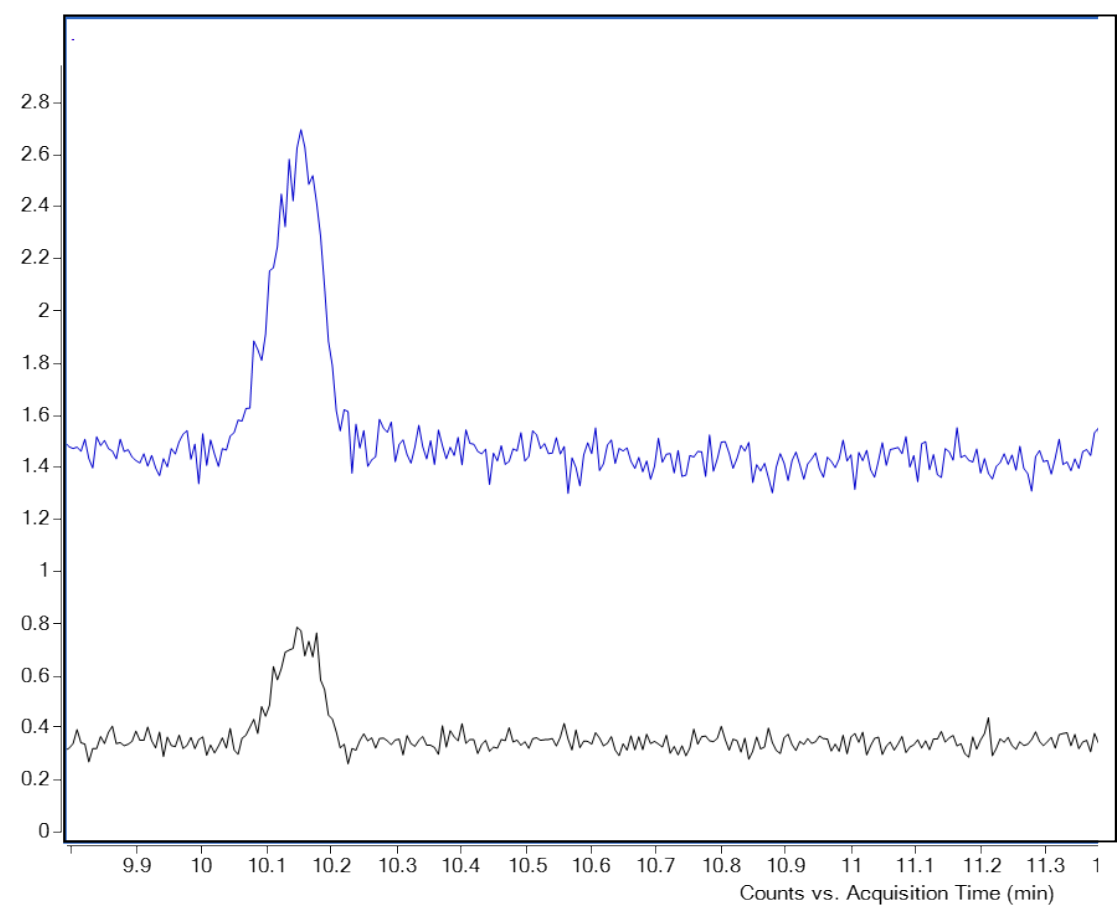

Figure 3. Chromatograph showing a syringe background sample (black, $\sim 6 \mathrm{ppm}$ ) and an effluent sample from the humid SM-3 test (blue, $\sim 12 \mathrm{ppm}$ ). $\mathrm{C}_{4} \mathrm{H}_{9} \mathrm{OH}$ (peak at $10 \mathrm{~min}$ ) is present in both samples, suggesting that contamination from the syringe could account for $\mathrm{C}_{4} \mathrm{H}_{9} \mathrm{OH}$ signals observed in the effluents of SM-2 and SM-3.

\subsection{SM-4 and SM-5: $\mathrm{C}_{4} \mathrm{H}_{9}$ I Thin Bed Tests}

The goal of these tests was to determine whether $\mathrm{C}_{4} \mathrm{H}_{9} \mathrm{OH}$ was present in the test effluent. The tests were designed to run until a $\mathrm{C}_{4} \mathrm{H}_{9} \mathrm{I}$ breakthrough was observed. One thin bed test was run with a dry air stream at a dew point of $-65^{\circ} \mathrm{C}$, and the second thin bed test was run under a humid air stream at a dew point of $0^{\circ} \mathrm{C}$. Both tests used $18 \mathrm{~g}$ of $\mathrm{AgZ}\left(\sim 1 \mathrm{in}\right.$. deep) and a $50 \mathrm{ppm} \mathrm{C}_{4} \mathrm{H}_{9} \mathrm{I}$ inlet stream. The dry test (SM-4) ran for $30 \mathrm{~h}$, and the humid test (SM-5) ran for $72 \mathrm{~h}$. In the dry test, the inlet concentration was increased to $100 \mathrm{ppm}$ after $24 \mathrm{~h}$ in an attempt to increase the concentration of any potential reaction products for easier detection. In the humid test, the concentration was held constant at $50 \mathrm{ppm}$ for the $72 \mathrm{~h}$ test.

No $\mathrm{C}_{4} \mathrm{H}_{9} \mathrm{OH}$ or other reaction products were detected in the dry test under a $50 \mathrm{ppm}$ stream or a $100 \mathrm{ppm}$ stream. After $29 \mathrm{~h}, \mathrm{C}_{4} \mathrm{H}_{9} \mathrm{I}$ breakthrough was observed.

Similarly, in the humid test, no $\mathrm{C}_{4} \mathrm{H}_{9} \mathrm{OH}$ was detected in any of the 10 effluent samples analyzed over 3 days. $\mathrm{C}_{4} \mathrm{H}_{9} \mathrm{I}$ breakthrough was detected in the effluent at $72 \mathrm{~h}$.

\subsection{SM-6 and SM-7: $\mathrm{C}_{4} \mathrm{H}_{9} \mathrm{I}$ and $\mathrm{C}_{4} \mathrm{H}_{9} \mathrm{OH}$ Burn-Off Tests}

With no detection of $\mathrm{C}_{4} \mathrm{H}_{9} \mathrm{OH}$ in the effluents of SM-4 and SM-5, consideration was given to the potential that $\mathrm{C}_{4} \mathrm{H}_{9} \mathrm{OH}$ might be produced and subsequently be retained by the sorbent bed. The goal of tests SM- 6 and SM-7 was to determine whether $\mathrm{C}_{4} \mathrm{H}_{9} \mathrm{OH}$ initially adsorbed to the $\mathrm{AgZ}$ during loading and could be removed at an elevated temperature. To test this possibility, $\mathrm{C}_{4} \mathrm{H}_{9} \mathrm{OH}$ was passed through a bed of $\mathrm{AgZ}$ at $150^{\circ} \mathrm{C}$ to establish any sorption. The $\mathrm{C}_{4} \mathrm{H}_{9} \mathrm{OH}$ flow was then discontinued, and the bed temperature was 
increased to $225^{\circ} \mathrm{C}$ while effluent samples were collected. $\mathrm{An}_{4} \mathrm{H}_{9} \mathrm{I}$ loaded test was sampled at the same temperature profile for comparison.

In test SM-6, a thin bed of AgZ (4 $g$ total mass) was contacted with a humidified gas stream that contained $50 \mathrm{ppm}_{4} \mathrm{H}_{9} \mathrm{I}$ for $168 \mathrm{~h}$ (Table 3). Effluent samples were collected downstream of the thin bed repeatedly to measure the breakthrough concentration. Throughout the loading period, the mean downstream effluent $\mathrm{C}_{4} \mathrm{H}_{9} \mathrm{I}$ concentration was $41 \mathrm{ppm}$.

In test SM-7, a thin bed of AgZ (4 g total mass) was contacted with a dry gas stream that contained $50 \mathrm{ppm}$ $\mathrm{C}_{4} \mathrm{H}_{9} \mathrm{OH}$ for $48 \mathrm{~h}$ (Table 3). Effluent samples were collected downstream of the thin bed during loading to measure the breakthrough concentration. Concentrations of $25 \mathrm{ppm}$ were detected in the downstream effluent after $2 \mathrm{~h}, 43 \mathrm{ppm}$ were detected downstream after $30 \mathrm{~h}$, and $31 \mathrm{ppm}$ were detected downstream after $48 \mathrm{~h}$. This fluctuating concentration is not readily explained. The downstream concentrations are lower than the inlet concentration, suggesting that $\mathrm{C}_{4} \mathrm{H}_{9} \mathrm{OH}$ was being adsorbed to the $\mathrm{AgZ}$ during the loading phase.

After loading, the beds were purged with dry air at $150^{\circ} \mathrm{C}$. Over the course of several hours, the bed temperature was increased to $160,175,200$, and $225^{\circ} \mathrm{C}$ with effluent samples collected at each temperature (Table 4). The boiling point of $\mathrm{C}_{4} \mathrm{H}_{9} \mathrm{OH}$ is $117^{\circ} \mathrm{C}$, which is well below the final temperature of the sorbent bed. Literature indicates that $\mathrm{C}_{4} \mathrm{H}_{9} \mathrm{OH}$ adsorbed on other similar zeolites will release at temperatures well below $200^{\circ} \mathrm{C}$ (Oudshoorn et al. 2012).

Table 4. Results of $\mathrm{C}_{4} \mathrm{H}_{9} \mathrm{I}$ and $\mathrm{C}_{4} \mathrm{H}_{9} \mathrm{OH}$ burn-off tests.

\begin{tabular}{|c|c|c|c|c|}
\hline GC sample & Effluent sample & $\begin{array}{l}\text { Temp. } \\
\left({ }^{\circ} \mathrm{C}\right)\end{array}$ & $\begin{array}{c}\mathrm{C}_{4} \mathrm{H}_{9} \mathrm{OH} \\
(\mathrm{ppm})\end{array}$ & $\begin{array}{l}\mathrm{C}_{4} \mathrm{H}_{9} \mathrm{I} \\
(\mathrm{ppm})\end{array}$ \\
\hline 1 & SM-6 $\mathrm{C}_{4} \mathrm{H}_{9} \mathrm{I}$ (loading) & 150 & $\mathrm{BDL}$ & 46 \\
\hline 2 & SM-7 $\mathrm{C}_{4} \mathrm{H}_{9} \mathrm{OH}$ (loading) & 150 & 31 & -- \\
\hline \multicolumn{5}{|c|}{ Stop $\mathrm{C}_{4} \mathrm{H}_{9} \mathrm{I}$ flow, continue air diluent } \\
\hline 3 & SM-6 $\mathrm{C}_{4} \mathrm{H}_{9} \mathrm{I}$ & 150 & $\mathrm{BDL}$ & 21 \\
\hline \multicolumn{5}{|c|}{ Stop $\mathrm{C}_{4} \mathrm{H}_{9} \mathrm{OH}$ flow, continue air diluent } \\
\hline 4 & $\mathrm{SM}-7 \mathrm{C}_{4} \mathrm{H}_{9} \mathrm{OH}$ & 150 & 3 & -- \\
\hline \multicolumn{5}{|c|}{ Raise temperature to $160^{\circ} \mathrm{C}$} \\
\hline 5 & SM-6 $\mathrm{C}_{4} \mathrm{H}_{9} \mathrm{I}$ & 160 & $\mathrm{BDL}$ & 16 \\
\hline 6 & $\mathrm{SM}-7 \mathrm{C}_{4} \mathrm{H}_{9} \mathrm{OH}$ & 160 & $\mathrm{BDL}$ & -- \\
\hline \multicolumn{5}{|c|}{ Raise temperature to $175^{\circ} \mathrm{C}$} \\
\hline 7 & SM-6 $\mathrm{C}_{4} \mathrm{H}_{9} \mathrm{I}$ & 175 & $\mathrm{BDL}$ & 14 \\
\hline 8 & SM-7 $\mathrm{C}_{4} \mathrm{H}_{9} \mathrm{OH}$ & 175 & $\mathrm{BDL}$ & -- \\
\hline \multicolumn{5}{|c|}{ Raise temperature to $200^{\circ} \mathrm{C}$} \\
\hline 9 & SM-6 $\mathrm{C}_{4} \mathrm{H}_{9} \mathrm{I}$ & 200 & $\mathrm{BDL}$ & $\mathrm{BDL}$ \\
\hline 10 & $\mathrm{SM}-7 \mathrm{C}_{4} \mathrm{H}_{9} \mathrm{OH}$ & 200 & $\mathrm{BDL}$ & -- \\
\hline \multicolumn{5}{|c|}{ Raise temperature to $225^{\circ} \mathrm{C}$} \\
\hline 11 & SM-6 $\mathrm{C}_{4} \mathrm{H}_{9} \mathrm{I}$ & 225 & $\mathrm{BDL}$ & $\mathrm{BDL}$ \\
\hline 12 & $\mathrm{SM}-7 \mathrm{C}_{4} \mathrm{H}_{9} \mathrm{OH}$ & 225 & $\mathrm{BDL}$ & -- \\
\hline
\end{tabular}




\subsection{SM-8: $\mathrm{CH}_{3}$ I Loading and Burn-Off}

One experiment was completed to determine whether $\mathrm{CH}_{3} \mathrm{OH}$ was detected during $\mathrm{CH}_{3} \mathrm{I}$ sorption on a thin bed of $\mathrm{AgZ}$ under humid conditions (Table 3). Fifty parts per million of $\mathrm{CH}_{3} \mathrm{I}$ in air was loaded on a thin bed of $\mathrm{AgZ}$ at $150^{\circ} \mathrm{C}$ and a dew point of $10^{\circ} \mathrm{C}$. Loading was initiated at a dew point of $0^{\circ} \mathrm{C}$ but was raised to $10^{\circ} \mathrm{C}$ after several hours. After 2 days of loading, the $\mathrm{CH}_{3} \mathrm{I}$ flow was stopped, and air was purged through the bed as the temperature was raised in $25^{\circ} \mathrm{C}$ increments to $225^{\circ} \mathrm{C}$. The effluent was sampled at each temperature increment.

During the loading portion of the test at $150^{\circ} \mathrm{C}$, transient $\mathrm{CH}_{3} \mathrm{OH}$ was identified in effluent in the $10^{\circ} \mathrm{C}$ stream but not in the $0^{\circ} \mathrm{C}$ stream. The observed $\mathrm{CH}_{3} \mathrm{OH}$ was detected at the correct mass to charge ratio and retention time, but did not form a statistically significant peak ( $2 \sigma$ above baseline) and could not be quantified.

During the loading portion of the test at $150^{\circ} \mathrm{C}, 50 \mathrm{ppm}$ of $\mathrm{CH}_{3} \mathrm{I}$ was consistently detected downstream of the bed. That is, only a fraction of $\mathrm{CH}_{3} \mathrm{I}$ present in the feed stream was sorbing to the $\mathrm{AgZ}$ during the loading period. This would be expected in a thin bed test in which the concentration of sorbate is assumed to be nearly unchanged across the bed. In contrast, the SM- $6 \mathrm{C}_{4} \mathrm{H}_{9} \mathrm{I}$ thin bed test, which ran under similar conditions $\left(150^{\circ} \mathrm{C}, 0^{\circ} \mathrm{C}\right.$ dew point, identical flow rates, $4 \mathrm{~g} \mathrm{AgZ} \mathrm{bed),} \mathrm{recorded} \mathrm{lower} \mathrm{breakthrough}$ concentrations with a mean of $41 \mathrm{ppm}$. This suggests that $\mathrm{C}_{4} \mathrm{H}_{9} \mathrm{I}$ sorbs onto $\mathrm{AgZ}$ differently than $\mathrm{CH}_{3} \mathrm{I}$. These data support observations from TGA testing that show $\mathrm{AgZ}$ experiencing a faster initial weight gain and reaching saturation more quickly for $\mathrm{C}_{4} \mathrm{H}_{9} \mathrm{I}$ sorption than for $\mathrm{CH}_{3} \mathrm{I}$ sorption (Figure 4).

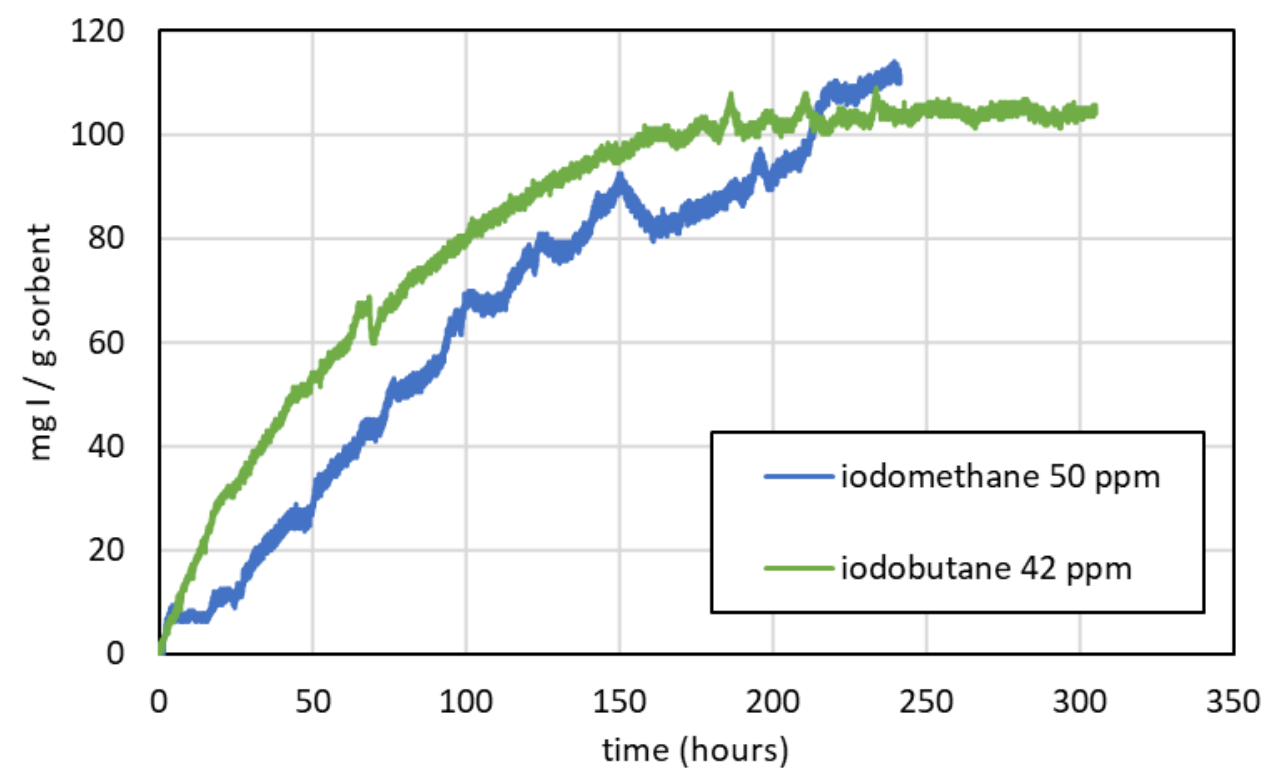

Figure 4. Loading rates of $\mathrm{CH}_{3} \mathrm{I}$ and $\mathrm{C}_{4} \mathrm{H}_{9} \mathrm{I}$ on thin bed tests recorded by TGA.

During the burn-off portion of the test, no $\mathrm{CH}_{3} \mathrm{I}$ or $\mathrm{CH}_{3} \mathrm{OH}$ was detected in the effluent stream. As soon as the $\mathrm{CH}_{3} \mathrm{I}$ loading flow was stopped, it disappeared from the effluent. This contrasts with the similar $\mathrm{C}_{4} \mathrm{H}_{9} \mathrm{I}$ test (SM-6) in which $\mathrm{C}_{4} \mathrm{H}_{9} \mathrm{I}$ was detected in the effluent stream for a few hours after the flow was stopped (between $150^{\circ} \mathrm{C}$ and $175^{\circ} \mathrm{C}$ ) (Table 4). This observation could indicate higher levels of physisorption for $\mathrm{C}_{4} \mathrm{H}_{9} \mathrm{I}$ on $\mathrm{AgZ}$ compared with $\mathrm{CH}_{3} \mathrm{I}$. 


\section{CONCLUSIONS AND FUTURE TESTS}

Thin bed $\mathrm{CH}_{3} \mathrm{I}$ tests conducted at a $10^{\circ} \mathrm{C}$ dew point resulted in the identification of $\mathrm{CH}_{3} \mathrm{OH}$ in the chromatograph at levels near the LOD, confirming literature observations and the experimental methodology used in these studies. To bolster this observation, testing with greater masses of sorbent can be performed to increase the amount of sorbent available for reaction and the corresponding amount of $\mathrm{CH}_{3} \mathrm{OH}$ produced to well above the LOQ.

$\mathrm{C}_{4} \mathrm{H}_{9} \mathrm{I}$ and $\mathrm{CH}_{3} \mathrm{I}$ show different loading rates in TGA tests and thin bed tests in which the effluent is analyzed downstream of the test. $\mathrm{C}_{4} \mathrm{H}_{9} \mathrm{I}$ sorbs to $\mathrm{AgZ}$ more quickly than $\mathrm{CH}_{3} \mathrm{I}_{2} \mathrm{C}_{4} \mathrm{H}_{9} \mathrm{I}$ is also released from the sorbent during burn-off, whereas $\mathrm{CH}_{3} \mathrm{I}$ is not.

Thin bed $\mathrm{C}_{4} \mathrm{H}_{9} \mathrm{I}$ tests conducted at $-65^{\circ} \mathrm{C}$ and a $0^{\circ} \mathrm{C}$ dew point did not result in $\mathrm{C}_{4} \mathrm{H}_{9} \mathrm{OH}$ detection in the effluent, strongly indicating that $\mathrm{C}_{4} \mathrm{H}_{9} \mathrm{I}$ sorption follows a different reaction pathway than $\mathrm{CH}_{3} \mathrm{I}$ sorption.

To finalize this experimental thrust before completing the comprehensive VOG testing program, select additional data will be collected. These actions will include: (1) determining the iodine content of each AgZ bed used in testing and (2) replicating SM-7 and SM-8 by using deep beds of $\mathrm{AgZ}$ to ensure that any $\mathrm{CH}_{3} \mathrm{OH}$ and $\mathrm{C}_{4} \mathrm{H}_{9} \mathrm{OH}$ produced are above the LOQ. These results will be included in the final end-of-year report.

\section{REFERENCES}

Azambre, B. and M. Chebbi. 2017. "Evaluation of Silver Zeolites Sorbents Toward Their Ability to Promote Stable $\mathrm{CH}_{3}$ I Storage as AgI Precipitates." ACS Applied Materials \& Interfaces 9(30): 25,19425,203 .

Bruffey, S. H., B. B. Spencer, D. M. Strachan, R. T. Jubin, N. R. Soelberg, and B. J. Riley. 2015. A Literature Survey to Identify Potentially Problematic Volatile Iodine-Bearing Species Present in Off-Gas Streams, FCR\&D-MRWFD-2015-000421, ORNL-SPR-2015/290, INL/EXT-15-35609.

Bruffey, S. H., R. T. Jubin, and J. A. Jordan. 2018. Quantify the Extent of Physisorption on Silver Based Sorbents under VOG Conditions, ORNL/SPR-2018/1066. Oak Ridge National Laboratory, Oak Ridge, Tennessee.

Chapman, K. W., P. J. Chupas, and T. M. Nenoff. 2010. "Radioactive Iodine Capture in Silver-Containing Mordenites through Nanoscale Silver Iodide Formation." Journal of the American Chemical Society 132(26): 8,897-8,899.

Chebbi, M., S. Chibani, J. F. Paul, L. Cantrel, and M. Badawi. 2017. "Evaluation of Volatile Iodine Trapping in Presence of Contaminants: A Periodic DFT Study on Cation Exchanged-Faujasite." Microporous and Mesoporous Materials 239: 111-122.

Chebbi, M., B. Azambre, L. Cantrel, and A. Koch. 2016. "A Combined DRIFTS and DR-UV-Vis Spectroscopic In Situ Study on the Trapping of $\mathrm{CH}_{3} \mathrm{I}$ by Silver-Exchanged Faujasite Zeolite," Journal of Physical Chemistry C 120: 18,694-18,706.

Greaney, A. T., and S. H. Bruffey. 2020. Effect of NOx and Water Variations on Iodine Loading of AgZ, ORNL/SPR-2021/1581, Oak Ridge National Laboratory, Oak Ridge, Tennessee.

Haefner, D. R., and T. L. Watson. 2010. Summary of FY2010 Iodine Capture Studies at the INL, INL/EXT-10-19657. 
Huve, J., A. Ryzhikov, H. Nouali, V. Lalia, G. Augé, and T. J. Daou. 2018. "Porous Sorbents for the Capture of Radioactive Iodine Compounds: A Review." RSC Advances 8(51): 29,248-29,273.

Jubin, R. T, N. R. Soelberg, D. M. Strachan, and G. Ilas. 2012. Fuel Age Impacts on Gaseous Fission Product Capture During Separations, FCRD-SWF-2012-000089.

Jubin, R. T., D. M. Strachan, and N. R. Soelberg. 2013. Iodine Pathways and Off-Gas Stream Characteristics for Aqueous Reprocessing Plants-A Literature Survey and Assessment, FCRD-SWF2013-000308, ORNL/LTR-2013/383, INL/EXT-13-30119.

Jubin, R. T., J. A. Jordan, and S. H. Bruffey. 2017. Performance of Silver-Exchanged Mordenite and Silver-functionalized Silica-Aerogel under Vessel Off-gas Conditions, ORNL/TM-2017/477, Oak Ridge National Laboratory, Oak Ridge, Tennessee.

Jubin, R. T., S. H. Bruffey, N. R. Soelberg, and A. K. Welty. 2018. Joint Test Plan for the Evaluation of Iodine Retention for Long-Chain Organic Iodides, NTRD-MRWFD-2018-000212, ORNL/SPR-2018/781.

Nenoff, T. M., M. A. Rodriguez, N. R. Soelberg, and K. W. Chapman. 2014. "Silver-Mordenite for Radiologic Gas Capture from Complex Streams: Dual Catalytic $\mathrm{CH}_{3} \mathrm{I}$ Decomposition and I Confinement." Microporous and Mesoporous Materials 200: 297-303.

Oudshoorn, A., L. A. M. Van der Wielen, and A. J. J. Straathof. 2012. "Desorption of Butanol from Zeolite Material." Biochemical Engineering Journal 67: 167-172.

Chebbi, M., B. Azambre, C. Monsanglant Louvet, B. Marcillaud, A. Roynette, and L. Cantrel. 2021. "Effects of Water Vapour and Temperature on the Retention of Radiotoxic $\mathrm{CH}_{3} \mathrm{I}$ by Silver Faujasite Zeolites." Journal of Hazardous Materials 409: 124,947.

Outotec, H. S. C. “Chemistry Software.” Version 9, 1974-2018.

Scheele, R. D., L. L. Burger, and C. L. Matsuzaki. 1983. Methyl Iodide Sorption by Reduced Silver Mordenite, PNNL-4489.

Soelberg, N. R., and T. L. Watson. 2016. FY-2016 Methyl Iodide Higher NOx Adsorption Test Report, INL/EXT-16-40087, Idaho National Laboratory, Idaho Falls, Idaho.

Tang, S., S. Choi, Y. Nan, and L. L. Tavlarides. 2020. "Adsorption of Methyl Iodide on Reduced Silver-Functionalized Silica Aerogel: Kinetics and Modeling." AIChE Journal e17137. 